\title{
UPAYA MENINGKATKAN PRESTASI BELAJAR SISWA KELAS VIII SMP NEGERI 2 PRAYA DENGAN PENERAPAN PEMBELAJARAN INDIVIDUAL PADA MATA PELAJARAN IPS TERPADU
}

\author{
L. MOH. ZAKI HARDI
}

SMP NEGERI 2 PRAYA, zakihardilm@gmail.com

\section{INFO ARTIKEL}

Riwayat Artikel:

Diterima: 01-03-2018

Disetujui: 15-04-2018

\section{Kata Kunci:}

Pembelajaran Individual, Aktivitas Belajar,

Prestasi Belajar.

\begin{abstract}
ABSTRAK
Abstrak: Penelitian Tindakan Kelas 2 siklus yang terdiri dari 4 tahapan yaitu tahap perencanaan, tahap observasi, tahap evaluasi, dan tahap refleksi dengan tujuan untuk mengetahui apakah penerapan pembelajaran individual mata pelajaran IPS dapat meningkatkan aktivitas dan prestasi belajar siswa kelas VIII semester II SMPN 2 Praya. Intrumen yang digunakan adalah lembar observasi, interview, dokumentasi, dan tes. Diperoleh hasil aktivitas siswa dan hasil evaluasi belajar dari 38 siswa yang mendapat nilai $\geq 65$ sebanyak 36 siswa. Disimpulkan bahwa penerapan pembelajaran idividual pada mata pelajaran IPS dapat meningkatkan aktivitas dan prestasi belajar siswa kelas VIII semester II SMPN 2 Praya.

Abstract: Class Action Research 2 cycle consisting of 4 stages that is planning stage, observation phase, evaluation phase, and reflection phase with the aim to know whether the application of individual learning subject of IPS can increase activity and achievement of student of class VIII second semester SMPN 2 Praya. The instruments used are observation sheets, interviews, documentation, and tests. Obtained result of student activity and result of evaluation learn from 38 student which get score 65 as 36 student. It was concluded that the application of idividual learning on social studies subjects can improve the activity and achievement of students of class VIII second semester of SMPN 2 Praya.
\end{abstract}

\section{A. LATAR BELAKANG}

Di dalam Undang-Undang Sistem Pendidikan Nasional No 14 Tahun 2005 diamanatkan bahwa pendidikan nasional bertujuan untuk mengembangkan potensi peserta didik agar menjadi manusia beriman dan bertaqwa kepada Tuhan Yang Maha Esa, berahlak mulia, sehat, berilmu, cakap, kreatif, mandiri dan menjadi warga negara yang demokratis serta bertanggungjawab.

Strategi pengembangan pendidikan nasional diarahkan pada 4 sasaran pokok yaitu: peningkatan kesempatan memperoleh pendidikan, peningkatan mutu pendidikan, relevansi dan efisiensi pendidikan. Dari ke empat sasaran tersebut masalah peningkatan mutu pendidikan adalah masalah yang perlu mendapat prioritas bagi penyelenggaraan pendidikan. Salah satu upaya yang ditempuh untuk meningkatkan kualitas pendidikan adalah dengan cara melakukan inovasi dalam pembelajaran.

Selama ini guru mengalami banyak kendala dalam pelajaran IPS Terpadu salah satu faktornya adalah pembelajaran yang digunakan oleh guru masih dominan menggunakan pembelajaran klasikal. Padahal hakikatnya dalam setiap siswa berbeda secara individu baik dalam prestasi belajarnya maupun kemampuan potensialnya. Menurut (Djamarah, 2010:1), bahwa paling sedikit ada tiga aspek yang membedakan anak didik yang satu dengan yang lainnya yaitu aspek intelektual, psikologis dan biologis. Perbedaan tersebut berpengaruh pada cara dan hasil belajar siswa, karenanya perbedaan individu perlu diperhatikan oleh guru dalam upaya pembelajaran. Perbedaan anak didik secara individu tersebut memberikan wawasan kepada guru bahwa strategi pembelajaran harus memperhatikan perbedaan anak didik pada aspek individu. Salah satu bentuk pemikiran untuk menangani persoalan tersebut adalah prinsip pendekatan individualisasi. Pendekatan individual mempunyai arti yang sangat penting bagi kepentingan pengajaran. Pengelolaan kelas sangat memerlukan pendekatan individual ini. Pemilihan metode tidak bisa begitu saja mengabaikan kegunaan pendekatan individual, sehingga guru dalam melaksanakan tugasnya selalu melakukan pendekatan individual terhadap anak didik di kelas. (Djamarah, 2010:55). Prinsip pendekatan individual tertuang dalam suatu pembelajaran individual yang mempunyai arti penting bagi kepentingan pengajaran.

Dengan demikian penerapan pembelajaran individual pada mata pelajaran IPS Terpadu sangat diharapkan pada proses pembelajaran untuk mencapai nilai ketuntasan minimum 65 . Hal ini berdasarkan pada kurikulum sebagai salah satu substansi pendidikan perlu didesentralisasikan terutama dalam pengembangan silabus dan pelaksanaannya yang disesuaikan dengan tuntutan kebutuhan siswa, keadaan dan kondisi sekolah. Dengan demikian sekolah memiliki cukup kewenangan untuk merancang dan menentukan materi pokok pembelajaran, kegiatan pembelajaran dan penilaian hasil pembelajaran.

Pembelajaran secara individual adalah kegiatan mengajar guru yang menitikberatkan pada bantuan dan bimbingan belajar kepada masing-masing individu, guru membantu siswa menghadapi kesukaran. Dari gambaran di atas, jelas dibutuhkan sistem pembelajaran IPS 
terpadu yang mampu meningkatkan prestasi belajar siswa juga memperhatikan perkembangan tingkah laku dan perbedaan kemampuan siswa dalam proses pembelajaran. Salah satu cara yang memungkinkan adalah dengan mengembangkan pembelajaran melalui pembelajaran individual.

Aktivitas siswa merupakan bentuk respon terhadap pendekatan belajar mengajar yang diterapkan oleh guru atau pendidik, misalnya guru berperan sebagai pemberi dorongan, motivasi, menggugah inisiatif dan inspirasi yang sangat diperlukan siswa untuk menemukan dan memecahkan masalah dengan kemampuan sendiri didukung oleh sarana dan prasarana yang telah disediakan sekolah untuk menunjang aktivitas belajar dan pembelajaran.

Motivasi belajar pada dasarnya ada di dalam diri siswa. Dalam kerangka pendidikan formal, motivasi belajar tersebut ada dalam jaringan rekayasa pedagogis guru. Dengan tindakan pembuatan persiapan mengajar, pelaksanaan belajar mengajar, maka guru menguatkan motivasi belajar siswa. Sebaliknya, dilihat dari segi emansipasi kemandirian siswa, motivasi belajar semakin meningkat pada tercapainya hasil belajar. Motivasi belajar merupakan segi kejiwaan yang mengalami perkembangan, artinya terpengaruh oleh kondisi fisiologis dan kematangan psikologis siswa. (Dimyati, 2009: 97)

\section{B. METODE PENELITIAN}

\section{Jenis Penelitian}

Jenis penelitiannya adalah penelitian tindakan kelas (Classroom Action Research) merupakan suatu pencermatan terhadap kegiatan belajar berupa sebuah tindakan, yang sengaja dimunculkan dan terjadi dalam sebuah kelas secara bersama, (Suharsimi, 2010:3). Pada hakekatnya merupakan penelitian yang dilakukan oleh guru dalam kelasnya sendiri melalui refleksi diri, dengan tujuan memperbaiki kinerjanya sebagai guru, sehingga hasil belajar siswa menjadi lebih meningkat. Jenis penelitian mampu menawarkan pendekatan dan prosedur baru yang lebih menjanjikan dampak langsung dalam bentuk peningkatan dan perbaikan dalam bentuk profesionalisme guru dalam mengelola proses belajar mengajar di kelas atau implementasi berbagai program di sekolahnya yang mengkaji berbagai indikator keberhasilan proses dan hasil implementasi dari berbagai program sekolah.

Perbaikan dilakukan secara bertahap dan terus menerus selama kegiatan penelitian dilakukan. Oleh karena itu di dalam penelitian tindakan kelas dikenal adanya siklus pelaksanaan berupa pola perencanaan, pelaksanaan, observasi, refleksi dan revisi (perencanaan ulang) pada siklus selanjutnya sampai mencapai target yang diinginkan.

\section{Gambaran Umum Lokasi Penelitian}

Lokasi penelitian merupakan tempat dimana dilakukan suatu penelitian. Lokasi penelitian dalam hal ini adalah bertempat di sekolah SMP Negeri 2 Praya. Adapun batas-batas umum dari SMP Negeri 2 Praya adalah sebagai berikut :

a. Sebelah utara berbatasan dengan Perkampungan Gerenjeng b. Sebelah selatan berbatasan dengan Jalan Raya/Pertokoan

c. Sebelah barat berbatasan dengan SMAN 1 Praya

d. Sebelah timur berbatasan dengan Jalan Raya/SDN 4 Praya

Objek dari penelitian tindakan kelas ini adalah siswa kelas VIII 3 SMP Negeri 2 Praya Tahun Ajaran 2012/2013 yang berjumlah 38 orang siswa.

\section{Metode Penentuan Subyek Penelitian}

Populasi merupakan seluruh subyek penelitian. Nawawi (2003) dalam Iskandar (2009 : 118) populasi adalah jumlah keseluruhan subyek penelitian yang dapat terdiri dari manusia, bendabenda, hewan, tumbuh-tumbuhan, gejala-gejala, nilai test atau peristiwa-peristiwa sebagai sumber data yang memiliki karakteristik tertentu di dalam suatu penelitian. Sedangkan menurut Sudjana (2005 : 74) populasi adalah totalitas semua nilai yang mungkin, hasil menghitung atau pengukuran, kuantitatif maupun kualitatif mengenai karakteristik tertentu dari semua anggota kumpulan yang lengkap dan jelas yang ingin dipelajari sifat-sifatnya.

Adapun yang menjadi populasi pada penelitian ini adalah seluruh siswa kelas VIII SMPN 2 Praya tahun pelajaran 2012/2013 yang berjumlah orang.

Sampel adalah bagian atau wakil dari populasi yang diteliti (Arikunto, 2006 : 87). Sedangkan dalam kamus besar bahasa Indonesia, sampel adalah suatu yang digunakan contoh dari bagian yang lebih besar. Sedangkan menurut Sugiyono (2003 : 56) sampel adalah "sebagian dari jumlah dan karakteristik yang dimiliki oleh populasi”.

Adapun yang menjadi sampel pada penelitian ini adalah semua siswa kelas VIII ${ }^{3}$ SMPN 2 Praya Tahun Ajaran 2012/2013 yang berjumlah 38 orang siswa.

\section{Metode Pengumpulan Data}

Dalam setiap penelitian apapun selalu dihadapkan dengan metode pengumpulan data yang digunakan. Metode pengumpulan data ini merupakan salah satu factor yang sangat penting dalam kegiatan penelitian. Penelitian disamping perlu menggunakan metode yang tepat, juga perlu memilih tehnik dan alat pengumpulan data yang relevan. Penggunaan tehnik dan alat pengumpul data memungkinkan diperolehnya data yang obyektif (S. Margono, 2002 : 158).

Dalam penelitian ini menggunakan metode atau tehnik yang dinamakan tehnik pengukuran. Tehnik pengukuran adalah alat pengumpul data yang bermaksud mengumpulkan data yang bersifat kuantitatif (S. Margono, 2002 : 170). Dalam tehnik pengukuran ini, alat yang digunakan adalah berupa pemberian tes.

Tes ialah seperangkat rangsangan (stimuli) yang diberikan kepada seseorang dengan maksud untuk mendapat jawaban yang dapat menjadikan skor angka (S. Margono, 2002 : 170). Adapun jenis tes yang umumnya dikenal dan digunakan sebagai alat pengukuran adalah tes lisan dan tes tertulis. Sejalan dengan itu pada penelitian ini lebih menghkususkan pada penggunaan tes tertulis. 
Tes tertulis yaitu berupa sejumlah pertanyaan yang diajukan secara tertulis tentang aspek-aspek yang ingin diketahui keadaannya dari jawaban yang diberikan secara tertulis pula (S. Margono, 2002 : 170). Tes tertulis ada dua bentuk yaitu tes essay atau tes uraian (essay test) dan tes obyektif.

\section{Jenis dan Sumber Data}

Mengetahui jenis data adalah hal yang mutlak dalam penelitian. Hal ini cukup beralasan karena dengan mengetahui data tersebut peneliti dapat mencari alternatif metode apa yang paling cocok sehubungan dengan jenis data yang tersedia. Menurut Sugiyono (2003 : 14) "Data penelitian dapat dikelompokkan menjadi dua yaitu data kualitatif dan data kuantitatif. Data kualitatif adalah data yang berbentuk kalimat, kata atau gambar. Sedangkan data kuantitatif adalah data yang berbentuk angka atau data kualitatif yang diangkakan (scoring)".

Menurut Surahmad (1998 : 134) "Sumber data menurut sifatnya digolongkan menjadi dua yaitu sumber data primer dan sumber data skunder. Sumber data primer adalah sumber yang memberikan data langsung dari tangan pertama. Sedangkan sumber data skunder adalah sumber yang dikutip dari sumber lain".

Berdasarkan keterangan tersebut, maka sumber data yang dipergunakan dalam penelitian ini adalah sumber data primer yang diperoleh langsung dari responden melalui tes yang dijawab oleh siswa sebagai responden.

\section{Identifikasi dan Definisi Operasional Variabel}

Agar tidak menimbulkan kesimpangsiuran tentang variable-variabel penelitian, maka perlu ditetapkan variable-variabel penelitian terlebih dahulu. Variabel merupakan objek penelitian (Arikunto, 2006:108). Variabel yang diamati dalam penelitian ini terdiri dari dua variabel yaitu satu variabel bebas adalah kondisi atau karaktekristik yang dimanipulasi untuk menerangkan dalam penelitian ini yaitu pembelajaran individual, sedangkan yang menjadi variabel terikatnya yaitu aktivitas dan prestasi belajar siswa

Untuk menghindari penafsiran yang berbeda terhadap beberapa istilah yang digunakan dalam penelitian ini, maka perlu dijelaskan beberapa istilah sebagai berikut :

\section{a. Aktivitas}

Menurut Hamid Apollo, (2002 : 23) kata aktivitas mempunyai arti sebagai berikut : keaktifan, kegiatan, kerja atau menjadi salah satu kegiatan kerja yang dilaksanakan dalam tiap bagian pada perkantoran, sekolah dan perusahaan atau tempat bekerja. Dengan demikian, kata aktivitas menurut peneliti mempunyai maksud, suatu kegiatan yang dapat dilaksanakan secara dinamis atau terus menerus untuk mendapatkan hasil yang diharapkan atau yang menjadi tujuan bersama.

\section{b. Motivasi}

Motivasi belajar pada dasarnya ada di dalam diri siswa. Dalam kerangka pendidikan formal, motivasi belajar tersebut ada dalam jaringan rekayasa pedagogis guru. Dengan tindakan pembuatan persiapan mengajar, pelaksanaan belajar mengajar, maka guru menguatkan motivasi belajar siswa. Sebaliknya, dilihat dari segi emansipasi kemandirian siswa, motivasi belajar semakin meningkat pada tercapainya hasil belajar.

\section{c. Prestasi Belajar}

Prestasi adalah hasil yang telah dicapai, dilakukan dan dikerjakan berupa kesankesan yang mengakibatkan perubahan dalam diri individu sebagai hasil dari aktivitas dalam belajar. (Hamid, Apollo 2002:511). Setiap usaha atau kegiatan yang dilakukan seseorang tentu mengharapkan hasilnya. Demikian halnya dengan kegiatan-kegiatan belajar yang dilakukan oleh anak tentu saja mengharapkan hasil dari usahanya itu. Hasil dari usaha belajar itulah yang disebut dengan prestasi belajar.

\section{d. Pembelajaran Individual}

Individu berarti pribadi, orang perseorang, person orang (nya) dan individual berarti perseorangan, tersendiri, bersifat pribadi, person. Masing-masing individu memiliki karakteristik yang berbeda-beda (Djamarah, 2010:62). Dari pengertian di atas dalam kaitannya dengan pembelajaran maka yang dimaksud dengan individu adalah siswa atau peserta didik yang melakukan kegiatan belajar atau mengikuti proses pendidikan yang memiliki ciri yang bervariasi.

\section{Rancangan Penelitian}

Penelitian tindakan kelas ini dilaksanakan dalam dua siklus, masing-masing siklus terdiri dari 4 tahap yaitu perencanaan, pelaksanaan tindakan, observasi dan evaluasi, refleksi. Secara rinci rancangan penelitian setiap siklus dapat dijabarkan sebagai berikut:

\section{Siklus I}

a. Perencanaan

Perencanaan merupakan kegiatan yang dilakukan pada siklus I dalam penerapan pembelajaran individual. Hal yang dapat dipersiapkan sebagai berikut:

Peneliti mensosialisasikan pengajaran dengan penerapan pembelajaran individual pada guru IPS Terpadu dengan cara:

1) Menyiapkan rencana pelaksanaan pembelajaran.

2) Menyiapkan lembar observasi

3) Menyusun alat evaluasi

4) Merencanakan analisis hasil tes.

b. Pelaksanaan Tindakan

Kegiatan yang dilaksanakan pada tahap ini adalah melaksanakan semua hal yang telah direncanakan pada tahap perencanaan dan direalisasikan dalam kegiatan pembelajaran di kelas.

Adapun langkah-langkah yang dilakukan dalam tindakan ini adalah sebagai berikut: 
1) Self Intruction (berinteraksi sendiri), siswa dibimbing untuk merencanakan kegiatan belajar, menetapkan tujuan belajar, dan membuat program belajar

2) Independent Study (belajar mandiri), siswa dituntut untuk melaksanaan belajar dan mengemukakan kriteria keberhasilan belajarnya

3) Individualized Prescribed Intruction, artinya siswa melaksanakan suatu yang telah ditentukan

4) Self Packet Learning (membuat paket belajar sendiri), siswa dibimbing untuk membuat paket belajar sendiri dalam bentuk ringkasan atau modul

5) Siswa mengakhiri kegiatan belajar dalam suatu unjuk hasil belajar dengan kriteria soal test yang ditentukan oleh guru sesuai dengan materi pembelajaran.

c. Observasi dan Evaluasi

Pada tahap ini dilakukan observasi terhadap pelaksanaan tindakan dengan menggunakan lembar observasi, dimana pada tahap ini peneliti dan siswa diobservasi oleh guru bidang studi tentang pelaksanaan kegiatan belajar mengajar, apakah pembelajaran telah sesuai dengan skenario yang dibuat atau tidak.

Pada akhir setiap siklus dilakukan evaluasi hasil belajar untuk mengetahui pemahaman atau penguasaan siswa terhadap konsep-konsep yang telah dipelajari. Soal evaluasinya dalam bentuk tes essay yaitu sejenis tes kemampuan belajar yang memerlukan jawaban yang bersifat pembahasan. Sasaran evaluasi adalah siswa yang terlibat dalam proses belajar mengajar.

d. Refleksi

Pada tahap ini, peneliti bersama guru akan mengkaji pelaksanaan dan hasil yang telah diperoleh dalam pemberian tindakan tiap siklus. Sebagai acuan dalam refleksi ini adalah hasil observasi dan evaluasi. Dari hasil observasi dan evaluasi siklus I, peneliti dan guru mengidentifikasi kekurangan yang muncul untuk melakukan dan penyempurnaan pada siklus berikutnya.

\section{Siklus II}

Siklus II dilakukan apabila pembelajaran pada siklus I belum berhasil mencapai ketuntasan belajar dan proses belajar-mengajar belum sesuai dengan apa yang diharapkan, sedangkan langkahlangkah yang dilakukan dalam siklus II pada dasarnya sama dengan langkah-langkah pada siklus I, hanya saja siklus II dilakukan perbaikan terhadap kekurangan pada siklus I.

TABEL 1

RINCIAN MATERI SIKLUS I DAN SIKLUS II

\begin{tabular}{|c|c|cc|cl|}
\hline $\begin{array}{c}\text { Sikl } \\
\text { us }\end{array}$ & $\begin{array}{c}\text { Pert } \\
\text { emu } \\
\text { an } \\
\text { ke }\end{array}$ & Indikator & Materi \\
\hline & 1 & 1. & $\begin{array}{l}\text { Mendeskripsik } \\
\text { an pengertian } \\
\text { pranata social } \\
\text { Mengidentifika } \\
\text { sirrangsi }\end{array}$ & 1. & $\begin{array}{l}\text { Pengertia } \\
\text { n pranata } \\
\text { social }\end{array}$ \\
& 2. & $\begin{array}{l}\text { Fungsi- } \\
\text { fungsi }\end{array}$ \\
\hline
\end{tabular}

\begin{tabular}{|c|c|c|c|}
\hline \multirow[t]{2}{*}{ I/II } & & $\begin{array}{ll} & \text { pranata social } \\
\text { 3. } & \text { Mendeskripsik } \\
\text { an proses } \\
\text { terjadinya } \\
\text { pranata social } \\
\text { 4. Mengidentifika } \\
\text { si cirri-ciri } \\
\text { pranata social }\end{array}$ & 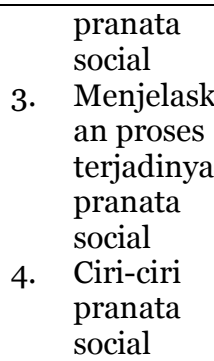 \\
\hline & 2 & & $\begin{array}{ll}\text { - } & \text { Evalu } \\
& \text { asi }\end{array}$ \\
\hline
\end{tabular}

\section{Analisa Data}

a. Data Aktivitas Siswa

Data aktivitas siswa dianalisis sebagai berikut: Menghitung skor aktivitas siswa dengan rumus

$$
A=\frac{\sum X}{i}
$$

Dengan:

$$
\begin{array}{ll}
\mathrm{A}= & \text { Rata-rata skor aktivitas siswa } \\
\mathrm{X}= & \text { Skor setiap diskriptor aktivitas siswa } \\
\mathrm{i}= & \text { Banyaknya diskriptor }
\end{array}
$$

Menentukan $\mathrm{Mi}$ dan SDi dengan rumus sebagai berikut:

$$
\begin{aligned}
& \mathrm{MI}=\frac{1}{2}(\text { skor tertinggi }+ \text { skor terendah }) \\
& \mathrm{SDI}=\frac{1}{6}(\text { skor tertinggi }- \text { skor terendah })
\end{aligned}
$$

Keterangan:

MI = Mean Ideal

SDI = Standar Deviasi Ideal TABEL 2

KRITERIA UNTUK AKTIVITAS BELAJAR SISWA

\begin{tabular}{|l|l|}
\hline \multicolumn{1}{|c|}{ Kriteria } & \multicolumn{1}{c|}{ Kategori } \\
\hline $\mathrm{Mi}+1,5 \mathrm{SDi} \leq \mathrm{A}$ & Sangat Tinggi \\
\hline $\mathrm{Mi}+0,5 \mathrm{SDi} \leq \mathrm{A}<\mathrm{Mi}+1,5 \mathrm{SDi}$ & Tinggi \\
\hline $\mathrm{Mi}-0,5 \mathrm{SDi} \leq \mathrm{A}<\mathrm{Mi}+0,5 \mathrm{SDi}$ & Cukup \\
\hline $\mathrm{Mi}-1,5 \leq \mathrm{A}<\mathrm{Mi}-0,5 \mathrm{SDi}$ & Kurang \\
\hline $\mathrm{A}<\mathrm{Mi}-1,5 \mathrm{SDi}$ & Sangat kurang \\
\hline
\end{tabular}

b. Data aktivitas guru

Setiap indikator prilaku guru pada penilaiannya mengikuti aturan sebagai berikut: BS (baik sekali) : Jika semua (4) diskriptor yang nampak

B (baik) : Jika ada (3) diskriptor yang C (cukup) : Jika ada (2) diskriptor yang nampak

K (kurang) : Jika ada (1) diskriptor yang nampak

Yang dimaksud nampak adalah ada terlihat kegiatan guru selama mengajar di kelas yang sesuai dengan skenario yang telah disiapkan diawal pelajaran. Kaitan antara aktivitas guru dengan hasil evaluasi siswa yaitu makin banyak diskriptor perilaku yang nampak dalam proses mengajar maka semakin berhasil guru itu dalam menerapkan ilmu-ilmunya sehingga siswa menjadi senang dan tingkat pemahaman siswa meningkat.

Menghitung skor aktivitas guru dengan rumus

$$
A=\frac{\sum X}{i}
$$


Dengan:

$\mathrm{A}=\quad$ Rata-rata skor aktivitas guru

$\mathrm{X}=\quad$ Skor setiap diskriptor aktivitas guru

$\mathrm{i}=\quad$ Banyaknya diskriptor

Menentukan Mi dan SDi dengan rumus sebagai berikut:

$\mathrm{MI}=\frac{1}{2}$ (skor tertinggi + skor terendah $)$

$\mathrm{SDI}=\frac{1}{6}$ (skor tertinggi - skor terendah $)$

Keterangan:

MI = Mean Ideal

SDI $=$ Standar Deviasi Ideal

TABEL 3

KRITERIA UNTUK AKTIVITAS GURU

\begin{tabular}{|l|l|}
\hline \multicolumn{1}{|c|}{ Kriteria } & \multicolumn{1}{c|}{ Kategori } \\
\hline $\mathrm{Mi}+1,5 \mathrm{SDi} \leq \mathrm{A}$ & Sangat Tinggi \\
\hline $\mathrm{Mi}+0,5 \mathrm{SDi} \leq \mathrm{A}<\mathrm{Mi}+1,5 \mathrm{SDi}$ & Tinggi \\
\hline $\begin{array}{l}\mathrm{Mi}-\mathrm{O}, 5 \mathrm{SDi} \leq \mathrm{A}<\mathrm{Mi}+ \\
\text { 0,5SDi }\end{array}$ & Cukup \\
\hline $\mathrm{Mi}-1,5 \leq \mathrm{A}<\mathrm{Mi}-\mathrm{0,5} \mathrm{SDi}$ & Kurang \\
\hline $\mathrm{A}<\mathrm{Mi}-1,5 \mathrm{SDi}$ & Sangat kurang \\
\hline
\end{tabular}

(Nurkencana,1999:100)

c. Data Prestasi Belajar Siswa

Untuk mengetahui prestasi belajar siswa, hasil tes belajar dianalisis secara kuantitatif deskriptif, yaitu dengan rumus sebagai berikut:

$$
K K=\frac{X}{Z} x 100 \%
$$

Keterangan:

KK = Ketuntasan klasikal

$\mathrm{X}=$ Jumlah seluruh siswa yang memperoleh nilai minimal 65

$\mathrm{Z}=$ Jumlah seluruh siswa yang mengikuti tes. (Sugiyono, 2003:97).

\section{HASIL DAN PEMBAHASAN}

Adapun rincian pelaksanaan dan hasil penelitian penerapan pembelajaran individual pada mata pelajaran IPS Terpadu untuk meningkatkan aktivitas dan prestasi belajar siswa kelas VIII 3 semester II SMP Negeri 2 Praya tahun pelajaran 2012/2013 dapat diuraikan dalam bagian-bagian berikut:

\section{Hasil Penelitian Siklus I}

\section{Perencanaan}

Adapun pada tahap ini, guru merencanakan dan mempersiapkan perangkat kegiatan pembelajaran yaitu:

a. Rencana pelaksanaan pembelajaran (RPP) pada lampiran 1

b. Lembar observasi aktivitas belajar siswa pada lampiran 6

c. Lembar observasi aktivitas mengajar guru pada lampiran 8

d. Alat evaluasi siswa seperti yang terlihat pada lampiran 2.

\section{Pelaksanaan Tindakan}

Kegiatan yang dilakukan pada tahap ini mulai dari tanggal 04 Mei 2013 yang terdiri dari satu kali pertemuan dan dilanjutkan dengan evaluasi yang dilaksanakan pada tanggal $11 \mathrm{Mei}$ 2013.
Hasil Observasi dan Evaluasi

a) Hasil Observasi

TABEL 4

HASIL OBSERVASI AKTIVITAS BELAJAR SISWA SIKLUS 1

\begin{tabular}{|c|l|c|}
\hline No & \multicolumn{1}{|c|}{ Indikator } & $\begin{array}{c}\text { Skor } \\
\text { Indikator } \\
\text { Siklus I }\end{array}$ \\
\hline 1. & $\begin{array}{l}\text { Antusiasme siswa dalam } \\
\text { mengikuti kegiatan } \\
\text { pembelajaran }\end{array}$ & 2,33 \\
\hline 2. & $\begin{array}{l}\text { Interaksi guru dengan } \\
\text { siswa }\end{array}$ & 1 \\
\hline 3. & $\begin{array}{l}\text { Aktivitas masing-masing } \\
\text { siswa dalam pembelajaran }\end{array}$ & 3,5 \\
\hline $4 \cdot$ & $\begin{array}{l}\text { Aktivitas siswa dalam } \\
\text { melakukan diskusi }\end{array}$ & 1,33 \\
\hline $5 \cdot$ & $\begin{array}{l}\text { Aktivitas siswa dalam } \\
\text { melaksanakan } \\
\text { pembelajaran }\end{array}$ & 1,33 \\
\hline 6. & $\begin{array}{l}\text { Interaksi siswa dengan } \\
\text { siswa }\end{array}$ & 1,5 \\
\hline $7 \cdot$ & $\begin{array}{l}\text { Partisipasi siswa dalam } \\
\text { menyimpulkan hasil } \\
\text { belajar }\end{array}$ & 13 \\
\hline Jumlah skor indikator siklus I & 7 \\
\hline Banyaknya indikator & 1,9 \\
\hline Rata-rata & Rendah \\
\hline Kategori &
\end{tabular}

Berdasarkan tabel di atas, antusias siswa dalam pembelajaran pada siklus I masih kurang. Sebagian besar siswa masih malu untuk bertanya dan mengemukakan pendapat. Selain itu juga siswa belum bisa menyimpulkan sendiri materi pelajaran yang telah dipelajarinya. Hal ini disebabkan karena pendekatan langsung ke siswa pada saat pembelajaran masih kurang.

Berdasarkan kriteria pengolahan aktivitas siswa pada pembelajaran siklus I, banyaknya siswa 38 orang, dan jumlah skor yang diperoleh 13 sehingga rata-rata skor aktivitas belajar siswa sebesar 1,9 ini berarti bahwa aktivitas belajar siswa tergolong rendah.

TABEL 5

HASIL OBSERVASI AKTIVITAS MENGAJAR GURU SIKLUS 1

\begin{tabular}{|c|l|c|}
\hline No & \multicolumn{1}{|c|}{ Indikator } & \multicolumn{1}{|c|}{$\begin{array}{c}\text { Skor } \\
\text { Indikator } \\
\text { Siklus I }\end{array}$} \\
\hline 1. & $\begin{array}{l}\text { Membangkitkan minat dan } \\
\text { motovasi siswa dalam } \\
\text { belajar }\end{array}$ & 4 \\
\hline 2. & $\begin{array}{l}\text { Memberikan apersepsi } \\
\text { kepada siswa }\end{array}$ & 2 \\
\hline $3 \cdot$ & $\begin{array}{l}\text { Menyampaikan meteri } \\
\text { pembelajaran }\end{array}$ & 3 \\
\hline $4 \cdot$ & $\begin{array}{l}\text { Mendamping siswa selama } \\
\text { pembelajaran LKS }\end{array}$ & 1 \\
\hline $5 \cdot$ & $\begin{array}{l}\text { Kemampuan menciptakan } \\
\text { suasana yang kondusuf }\end{array}$ & 2 \\
\hline 6. & $\begin{array}{l}\text { Bersama siswa membuat } \\
\text { kesimpulan }\end{array}$ & 16 \\
\hline Jumlah skor indikator siklus I & 6 \\
\hline Banyaknya indikator & 2,7 \\
\hline Rata-rata aktivitas guru & Baik \\
\hline Interval & \\
\hline Kategori &
\end{tabular}


Berdasarkan tabel di atas, hasil observasi kegiatan guru dalam proses belajar mengajar sudah sesuai dengan skenario pembelajaran, walaupun masih terdapat kekurangankekurangan, diantaranya kurangnya pendekatan kepada siswa pada saat pembelajaran berlangsung.

b) Evaluasi

Evaluasi dilaksanakan tanggal 11 Mei 2013. Adapun hasil evaluasi pada siklus I dapat dadeskibsikan bahwa nilai rata-rata yang diperoleh pada siklus I adalah 69,21 dengan prosentase ketuntasan belajar siswa adalah $68,42 \%$ sehingga masih ada 12 siswa yang nilainya kurang dari 65 maka perlu dilanjutkan ke siklus berikutnya dan sebelum dilanjutkan dilakukan perbaikan terlebih dahulu dan ke -12 siswa tersebut perlu mendapat bimbingan dan pendekatan khusus secara individu.

c) Refleksi

Berdasarkan hasil observasi dan evaluasi pada siklus I, guru perlu membimbing siswa secara khusus agar lebih aktif lagi dalam pembelajaran serta membangkitkan minat dan motivasi siswa agar antusias dalam belajar, pengaplikasian soal lebih ditingkatkan sehingga siswa lebih berpengalaman dan dapat dengan mudah menyelesaikannya serta mampu menyimpulkan sendiri materi pelajarannya.

Memperhatikan permasalahan di atas, maka rencana perbaikan yang akan dilakukan pada siklus I agar nantinya tidak terulang pada siklus berikutnya adalah sebagai berikut:

1) Meningkatkan bimbingan kepada siswa secara individual dengan cara memperhatikan letak kelemahan/kekurangan siswa kemudian membimbingnya agar dalam pembelajaran selanjutnya siswa tidak mengalami kesulitan.

2) Guru memotivasi siswa agar lebih giat dalam belajar dan membiasakan untuk mengajukan pertanyaan apabila mendapat masalah dalam belajar.

\section{Hasil Penelitian Siklus II Perencanaan}

Tahap perencanaan siklus II sama halnya dengan tahap perencanaan siklus I dimana guru merencanakan dan mempersiapkan perangkat kegiatan pembelajaran yaitu:

a. Rencana pelaksanaan pembelajaran (RPP)

Lembar observasi aktivitas belajar siswa

b. Lembar observasi aktivitas mengajar guru

c. Alat evaluasi siswa seperti yang terlihat pada Proses pembelajaran pada tahap ini menjelaskan kembali tentang materi yang telah disampaikan pada siklus sebelumyan dengan meningkatkan bimbingan kepada siswa secara individual untuk aktif dalam bertanya jawab dan diskusi terutama yang berkaitan dengan cara menyelesaikan soalsoal yang diberikan pada evaluasi sebelumnya dengan memperhatikan kelemahan atau kekurangan siswa pada proses pembelajaran sebelumnya. Hal ini dibarengi dengan memotivasi siswa agar lebih giat dalam belajar dan membiasakan diri untuk mengajukan pertanyaan apabila mendapat masalah dalam belajar.

\section{Pelaksanaan Tindakan}

Pelaksanaan tindakan pada siklus II dilaksanakan dalam satu kali pertemuan yang dilaksanakan pada tanggal 18 Mei 2013 dan pelaksanaan evaluasi pada tanggal 25 Mei 2013.

\section{Hasil Observasi dan Evaluasi}

a) Hasil Observasi

TABEL 6

HASIL OBSERVASI KEGIATAN BELAJAR SISWA SIKLUS II

\begin{tabular}{|c|l|c|}
\hline No & \multicolumn{1}{|c|}{ Indikator } & $\begin{array}{c}\text { Skor } \\
\text { Indikator } \\
\text { Siklus II }\end{array}$ \\
\hline 1. & $\begin{array}{l}\text { Antusiasme siswa dalam } \\
\text { mengikuti kegiatan } \\
\text { pembelajaran }\end{array}$ & 3,7 \\
\hline 2. & Interaksi guru dengan siswa & 3 \\
\hline $3 \cdot$ & $\begin{array}{l}\text { Aktivitas masing-masing } \\
\text { siswa dalam pembelajaran }\end{array}$ & 3 \\
\hline $4 \cdot$ & $\begin{array}{l}\text { Aktivitas siswa dalam } \\
\text { melakukan diskusi }\end{array}$ & 3 \\
\hline $5 \cdot$ & $\begin{array}{l}\text { Aktivitas siswa dalam } \\
\text { melaksanakan } \\
\text { pembelajaran }\end{array}$ & 3,7 \\
\hline 6. & $\begin{array}{l}\text { Interaksi siswa dengan } \\
\text { siswa }\end{array}$ & 4 \\
\hline $7 \cdot$ & $\begin{array}{l}\text { Partisipasi siswa dalam } \\
\text { menyimpulkan hasil belajar }\end{array}$ & 4 \\
\hline \multicolumn{2}{|l|}{ Jumlah skor indikator siklus II } & 24,4 \\
\hline \multicolumn{2}{|l|}{ Ranyaknya indikator } & 7 \\
\hline \multicolumn{2}{|l|}{ Kata-rata } & 3,48 \\
\hline
\end{tabular}

Berdasarkan tabel di atas, antusias siswa dalam pembelajaran sudah mulai meningkat, hal ini terlihat pada sebagian besar siswa sudah bisa menjawab pertanyaan guru serta berani bertanya dan mengemukakan pendapat kepada guru. Selain itu juga siswa sudah bisa menyimpulkan sendiri materi pelajaran yang sedang dipelajarinya.

TABEL 7

HASIL OBSERVASI AKTIVITAS MENGAJAR GURU SIKLUS II

\begin{tabular}{|c|l|c|}
\hline No & \multicolumn{1}{|c|}{ Indikator } & $\begin{array}{c}\text { Skor } \\
\text { Indikator } \\
\text { Siklus II }\end{array}$ \\
\hline 1. & $\begin{array}{l}\text { Membangkitkan minat dan } \\
\text { motovasi siswa dalam } \\
\text { belajar }\end{array}$ & 4 \\
\hline 2. & $\begin{array}{l}\text { Memberikan apersepsi } \\
\text { kepada siswa }\end{array}$ & 4 \\
\hline $3 \cdot$ & $\begin{array}{l}\text { Menyampaikan meteri } \\
\text { pembelajaran }\end{array}$ & 3 \\
\hline $4 \cdot$ & $\begin{array}{l}\text { Mendamping siswa selama } \\
\text { pembelajaran LKS }\end{array}$ & 4 \\
\hline $5 \cdot$ & $\begin{array}{l}\text { Kemampuan menciptakan } \\
\text { suasana yang kondusuf }\end{array}$ & 4 \\
\hline 6. & $\begin{array}{l}\text { Bersama siswa membuat } \\
\text { kesimpulan }\end{array}$ & 4 \\
\hline Jumlah skor indikator siklus II & 23 \\
\hline \multicolumn{2}{|l|}{ Banyaknya indikator } & 3,83 \\
\hline \multicolumn{2}{|l|}{ Rata-rata aktivitas guru } & $3.05 \leq \mathrm{A}$ \\
\hline \multicolumn{2}{|l|}{ Katerval } & Sangat Baik \\
\hline
\end{tabular}


Hasil observasi kegiatan guru menunjukkan bahwa kegiatan belajar mengajar berjalan baik atau sesuai dengan apa yang direncanakan sebelumnya. Hal ini terlihat dari penguasaan kelas serta aplikasi pembelajaran individual sehingga kegiatan pembelajaran berjalan dengan baik.

b) Evaluasi

Hasil evaluasi pada siklus II lebih baik dibandingkan dengan siklus I sebagaimana terlihat pada pada tabel di atas yang menunjukkan bahwa 36 siswa telah tuntas yakni dengan memperoleh nilai $\geq 65$. Ini berarti indikator penelitian atau ketuntasan belajar dengan menerapkan pembelajaran individual telah tercapai sehingga penelitian dihentikan pada siklus ini yakni siklus II.

c) Refleksi

Berdasarkan hasil observasi dan evaluasi pada siklus II, guru sudah mampu memotivasi siswa serta mengaktifkan siswa dalam proses belajar mengajar dan semua berjalan sesuai dengan yang diharapkan walaupun tidak semua siswa memiliki semangat yang sama dalam belajar sehingga bimbingan siswa sangat dibutuhkan.

Program pembelajaran individual berorientasi pada pemberian bantuan kepada setiap siswa agar siswa dapat belajar mandiri. Dalam pelaksanaannya guru berperan sebagai fasilitator, pendiagnosis kesukaran belajar serta rekan diskusi (Sagala, 2010:184). Pelaksanaan pembelajaran individual juga membutuhkan waktu yang relatif banyak, hal ini terlihat dari presentase ketuntasan klasikal yang dimana masih ada dua orang siswa yang belum tuntas meskipun proses pembelajaran berlangsung dua siklus.

Berdasarkan hasil observasi pada siklus I, antusias pembelajaran masih kurang hal ini terlihat dari sebagian besar siswa masih malu bertanya serta ragu untuk menjawab. Selain itu juga siswa belum bisa menyimpulkan materi pelajaran yang sedang dipelajarinya. Hal ini disebabkan karena kurangnya aplikasi pembelajaran individual. Sedangkan pada siklus II sebagian besar siswa sudah mulai aktif bertanya dan tanpa ragu menjawab/menanggapi pertanyaan dari guru maupun dari temannya. Selain itu juga siswa sudah mampu menyimpulkan sendiri materi pelajaran yang sedang dipelajarinya. Begitu juga pada pertemuan kedua menunjukkan kecenderungan antusiasme dan aktivitas belajar siswa yang cenderung meningkat.

Berdasarkan hasil observasi pada siklus II, antusias pembelajaran semakin tinggi. Hal ini tercermin dari siswa yang saling berebut untuk mengerjakan soal yang diberikan oleh guru. Selain itu juga siswa aktif bertanya serta tanpa ragu untuk menanggapi pertanyaan temannya.

Proses belajar didorong oleh motivasi instrinsik siswa. Disamping itu proses belajar juga dapat terjadi atau menjadi bertambah kuat bila didorong oleh lingkungan siswa. Dengan kata lain aktivitas belajar dapat meningkat bila program pembelajaran disusun dengan baik (Dimyati, 2009:247).

Hasil evaluasi siklus I menunjukan bahwa masih ada 12 siswa yang nilainya $<65$, ini berarti 12 siswa masih belum tuntas. Hal ini disebabkan oleh beberapa faktor yakni kurangnya aplikasi pembelajaran individual Dimana guru kurang melakukan pendekatan langsung ke siswa sehinga menyebabkan kurangnya antusias siswa dalam pembelajaran sehingga perlu diadakan perbaikan pada siklus berikutnya yakni siklus II. Siklus II merupakan perbaikan dari siklus I yang mana tahaptahap dari siklus II sama dengan tahap-tahap pada siklus I. Akan tetapi sebelum dilanjutkan ke siklus II perlu diadakan refleksi dan revisi untuk perbaikan di siklus berikutnya. Pada siklus II, aplikasi pembelajaran individual lebih ditingkatkan sehingga siswa lebih antusias dalam memperhatikan pembelajaran, berani mengajukan pertanyaan serta mengemukakan pendapat, aktif melakukan kegiatan diskusi, menanggapi pertanyaan dari temannya dan mampu menyelesaikan soal-soal yang diberikan oleh guru. Hasil evaluasi pada siklus II menunjukkan peningkatan dari siklus sebelumnya.

Hal ini sesuai dengan teori pembelajaran individual, dimana pembelajaran individual merupakan usaha untuk memperbaiki kelemahan dari pembelajaran klasikal sehingga dapat meningkatkan prestasi belajar siswa (Dimyati, 2009:161).

\section{SIMPULAN DAN SARAN}

\section{Simpulan}

1. Penerapan pembelajaran individual pada mata pelajaran IPS Terpadu dapat meningkatkan prestasi belajar siswa kelas VIII 3 SMP Negeri 2 Praya Tahun Ajaran 2012/2013. Hal ini terlihat dari hasil evaluasi belajar siswa, yang mana dari keseluruhan siswa hanya 2 orang yang belum tuntas.

2. Penerapan pembelajaran individual pada mata pelajaran IPS Terpadu dapat meningkatkan aktivitas belajar siswa kelas VIII ${ }^{3}$ SMP Negeri 2 Praya Tahun Ajaran 2012/2013. Hal ini terlihat dari hasil observasi belajar siswa yang menunjukkan peningkatan aktivitas belajar siswa.

3. Pembelajaran individual menitikberatkan pada pemberian bantuan atau bimbingan langsung kepada masing-masing individu.

\section{Saran}

4. Bagi siswa diharapkan membiasakan diri untuk menanyakan materi yang dianggap sulit dan belum dimengerti serta tanpa ragu menanggapi pertanyaan-pertanyaan dari guru maupun teman-temannya.

5. Diharapkan kepada guru agar memperhatikan karakteristik anak didiknya dan memperlakukan sesuai karakteristiknya sehingga dapat meningkatkan prestasi belajarnya.

6. Bagi peneliti untuk kedepannya diharapkan dapat lebih profesional dalam menerapkan pembelajaran individual.

7. Bagi Institusi khususnya SMP Negeri 2 Praya agar dapat menerapkan pembelajaran individual untuk meningkatkan prestasi belajar siswa. 


\section{UCAPAN TERIMA KASIH}

Dengan penuh rasa hormat, saya ucapkan teimakasih kepada:

Kepala Dinas Pendidikan yang telah memfasilitasi, mengizinkan penulis untk mengadakan penelitian hingga dapat terlaksana dengan baik.

Kepala SMPN 2 Praya yang turut memotivasi untuk terlaksananya penelitian di sekolah secara reguler.

Guru-guru yang telah memberi dukungan baik secara moral maupun tindakan langsung dalam pelaksanaan penelitian ini.

\section{DAFTAR RUJUKAN}

[1] Ali, Mohamad, 1983. Guru Dalam Proses Belajar Mengajar, Bandung; Sinar Baru, Cet. VIII, 1992

[2] Aqib, Zainal. 2003. Profesionalisme Guru Dalam Pembelajaran. Insane cendekia; Surabaya

[3] Arifin (1991). Proses Komunikasi Antara Pendidik Dan Anak Didik. Jakarta: Dirjen Pembinaan Kelembagaan Agama Islam Dan Universitas Terbuka

[4] Arikunto, Suharsimi, dkk. 2006. Prosedur Penelitian Suatu Pendekatan Praktek. Jakarta: Rineka Cipta.

[5] Arikunto, Suharsimi, dkk. 2006. Penelitian tindakan kelas. Jakarta: Bumi Aksara

[6] Chalijah Hasan, Dimensi-Dimensi Psikologi Pendidikan. Al-ikhlas, Surabaya, cet. VII, 1990

[7] Dimyati dan Mudjiono, 2009. Belajar dan Pembelajaran. Jakarta : Rineka Cipta

[8] Djamarah, S, B. dan Zainal Aswan, 2010. Strateg Belajar Mengajar. Jakarta : Rineka Cipta

[9] Hamid, Farida. 2002. Kamus Ilmiah Popular Lengkap. Apollo: Surabaya

[10] Hamalik, Oemar, 2001. Pendekatan Baru Strategi Belajar Mengajar Berdasarkan Cbsa. Bandung: Sinar Baru Algesindo

[11] Iskandar, 2009. Metodelogi Penelitian Pendidikan Dan Social (Kuantitatif Dan Kualitatif). Jakarta : Gaung Persada Pres.

[12] Nurkencana, 1999. Evaluasi Pendidikan. Surabaya: Usaha Nasional.

[13] Ngalim Purwanto, Ilmu Pendidikan Teoritis Dan Praktis, remaja rosdakarya, bandung, cet.V.1991

[14] Sagala, M Syaiful.2010. Konsep dan makna pembelajaran. Alfabeta: bandung

[15] Sugiyono, 2003. Metode Penelitian Kuantitatif, Kualitatif, dan $R \& D$. Bandung: Alfabeta.

[16] S. Margono, 2002. Metode Penelitian Pendidikan. Rineka Cipta Jakarta

[17] Sri Kartanto, dkk. 2006. Ilmu Pengetahuan Social (IPS) Terpadu Untuk Kelas VIII. Penerbit CV. Teguh Karya: Surakarta. 